\title{
THE IMPROVEMENT OF CHILDREN'S INDEPENDENT LIVING SKILLS IN THE CONTEXT OF THE RESTRUCTURING OF CHILDREN'S CARE HOMES
}

\author{
Vida Gudžinskienė \\ Mykolas Romeris University, Lithuania \\ Rita Raudeliūnaitè \\ Mykolas Romeris University, Lithuania
}

\begin{abstract}
The article analyses the improvement of children's independent living skills in the context of the restructuring of children's care homes. The concept of the restructuring of institutional care is presented. A qualitative-empirical study has been conducted by using the method of a semi-structured interview. The study data were processed by using the method of content analysis. The results of the empirical study are based on the experience of 14 social workers, who work in care institutions, which participate in the restructuring, which consists of the changeover from institutional care to the services that are provided to children, who have become destitute of parental care, in a family and community. Three directions of the improvement of children's independent living skills in the context of the restructuring of children's care homes have been highlighted: increasing independence in adolescents (the engagement of children in a practical activity and their reasoning by encouraging and stimulating them for an independent activity); the improvement of the organisation of educational process (the increase of practical exercises, the reduction of the number of nurtures in a household, the increase of an individual communication with a child); the improvement of material basis (fund raising and the redistribution of the resources available).
\end{abstract}

Keywords: care homes, children, independent living skills, restructuring of institutional care.

\section{Introduction}

According to the Statistics Lithuania, 532647 children were growing in Lithuania at the beginning of 2014. At the end of 2014, 1.82 per cent of all the children, who resided in Lithuania, were without parental care (the Report on the Activity of the State Child Rights Protection and Adoption Service of 2014). Despite the work with social risk families, a considerable number of children are still separated from their parents every year. According to the data of the State Child Rights Protection and Adoption Service, at the present time, 3562 children are taken care of in 95 care institutions.

Children leave care homes once they reach the age of majority. The studies (Leliūgienè \& Djačenko, 2010) show that the beginning of an independent life 
of the educatees of care institutions, having left this institution, is complicated due to different social, pedagogical, psychological factors which negatively affect the social adaptation of a young person. The transition of the adolescents in care to an independent life is very sudden: in many instance they have to leave a care home and overcome all the challenges of an adult life at once, upon reaching the age of 18 and being poorly equipped for an independent life (Hojer \& Sjoblom, 2010). According to the data of the study by D. Rèklaitiene et al. (2008), half of the senior and a little younger adolescents, who reside in children's care, feel ill equipped for an independent life. Fewer than one-third of the senior educatees of children's care homes and one-fourth of the younger ones stated being well-equipped.

Although it is sought to establish conditions in care institutions that children would acquire a necessary social experience and would be able to integrate into society, however, the studies show that it is very difficult to ensure the best interests and comprehensive development of the child in such institutions (Snieškienè \& Bumblauskaitè, 2005). The process of the preparation for an independent life in children's care homes is more complicated due to the specificities of educational system when a family is changed by an institutional authority, in which, not rarely, one-sided, formal work is carried out with the educatees, possibilities are not given to them to act and solve life problems independently, to try different social roles, to draw experience from life, whereas that does not create favourable conditions for the development and expression of a socially active personality, aggravates the acquisition of skills which are necessary while living independently (Samašonok, 2013).

Large systems of institutional children's care make a negative impact on child development. According to D. Pūras (2013), it should always be borne in mind that better nutrition, heating, better care and the eradication of the instances of deliberate violence will not solve the deepest problems of institutional care. The social skills of children, who have lost parental care and are put to residential institutions of social care, in which permanently from several dozens to a few hundred children reside, whose social ties with their community due to the specific features of these institutions are limited, are weak, their opportunities for the integration into society are minimal (Keymolen \& Broeders, 2010). A feature of these institutions is group and not individual care of a person, institutional culture (Strolin-Goltzman, 2010). Residential care institutions are not able to ensure person-oriented services and appropriate support which is necessary for a successful integration of a person into society, limit the abilities and preparedness of the children, who grow in institutions, to participate in their community and society (Common European Guidelines on the Transition from Institutional to Community Based Care, 2012). The studies, which have been conducted in Lithuania and Europe, 
showed that institutional care always determines lower quality of life than high quality services, which are provided in the community, and often determines lifelong social seclusion (The Situation of Children's Rights in Lithuanian Residential Care and Education Institutions, 2006).

In Lithuania, the aspiration to give priority to child-care in the family and to reform children's care system was set out in the implementing measures of the programme of the Government for 2001-2004 and in the Conceptual State Policy on Children's Welfare adopted by the resolution of the Seimas of 2003. The reform of children's care system was begun in 2007, having adopted the Strategy for Lithuanian Child-Care System Reorganisation, the main purpose of which is, by 2012, having taken into consideration child's interests and needs, to establish conditions for a child to grow in his biological family, whereas, for a child, who has lost parental care, to create appropriate care or adoption conditions which would correspond the best interests of the child and the need to grow in a family environment or in a family-like environment, which is suitable for the preparation for an independent life in the family and society. This reform has not been completed to this day. Based on the data of the National Audit Office of Lithuania (2013), it should be noted that the objectives set out in the Strategy for Lithuanian Child-care System Reorganisation (2007) were not attained: the fraction of children, who have lost parental care, was not reduced (in comparison with all the children of the country), the fraction of children growing up in social risk families did not decrease (in comparison with all the children of the country), the percentage of children, who are care for in care institutions, did not decrease (in comparison with all the children in care), there is a predominance of a large number of children in care institutions, not in all the care institutions an environment that is a family-like environment has been created and the necessary needs of a child are not ensured, children's abilities, which are necessary for an independent living etc., are not developed sufficiently.

The order of the Minister Social Security and Labour of December 18, 2013 adopted The Action Plan for the Transition from Institutional Care to the Family and Community Based Services to the Children with Disabilities and the Children who Have Lost Parental Care for 2014-2020. The purpose of the transition of residential institutions for children from institutional care to family and community-based provision of the services to the children, who have lost parental care, is to ensure a harmonious environment and conditions to the children, who have lost parental care, to grow in the family or household of guardians or adoptive parents and receive assistance in the community. It is important for a child to grow in a family environment which stimulates children's independence, full and complete participation in the community and social inclusion. When restructuring children's care homes, it is foreseen to 
create new and expand the existing community services which are alternative to institutional care: communal children's care homes of up to 8 children when they are given residence in flats, houses; protected housing/ independent living homes to those who leave care, by providing "an accompanying assistance and care in a guardian family, care in a household etc. One of the priorities of the restructuring of children care is to prepare a child for an independent life. While the process of restructuring is underway no studies, which analyse the improvement of the preparation of children, who reside in children's care homes, for an independent life in the context of the restructuring, have been conducted. Therefore, it is relevant to conduct studies on the improvement of the development of independent life skills in children in the context of the restructuring of care homes.

The goal of the study is to reveal the directions of the improvement of the development of independent life skills in children in the context of the restructuring of children's care homes based on the experience of social workers.

\section{Research methodology}

Research methods. Qualitative research type was chosen for the study. According to J. W. Creswell (2009), the purpose of a qualitative study is to research complex phenomena with the properties that are characteristic of them and present the meanings and approaches, that were expressed by the participants of a study, on a researched phenomenon. In the study, the method of a semi-structured interview, which enables to come close to the understanding of human experiences, designation of meanings, the definition of meanings and the construction (explanation) of reality, was used. This article overviews one problematic question: what directions of the improvement of the development of independent life skills in children social workers identify. The obtained data were analyzed by the content analysis method. Qualitative content analysis was carried out in accordance with the inductive, study data based and categories composed logic. According to J.W. Creswell (2009), content analysis is a technique which, having examined the specificities of the text, allows, objectively and systematically, draw reliable conclusions. The qualitative content analysis was performed regarding the following sequence (Creswell, 2009): repeated reading of the content of transcript interview texts, distinction of meaning elements in the text analysed, grouping of the distinguished meaning elements into categories and sub-categories, integration of the categories/subcategories into the context of the phenomenon analysed and description of their analysis. 
The sample of the research. Criteria-based sample was used in the study. The informants were chosen according to the following criteria: 1) social workers who have a degree in social work, 2) social workers who work in care institutions, that take part in restructuring, which consists of the transition from institutional care to services, which are provided to children, who have lost parental care, in a family and community; 3) social workers whose length of their working time in children's care homes is at least 5 years; 4) 3 recent years of work with adolescents who are about to leave children's care homes.

The study was conducted in the September-October of 2015 in children's care homes chosen for restructuring according to "The List of Residential Social Care Institutions and the Homes of Infants with Impaired Development Selected for Restructuring" (2015). 14 social workers (all female) participated in the study.

Ethics of the research. The permission of the heads of children's care homes to conduct the research in their organisation has been obtained. Personal permission of the informants to take part in the research was sought. The researchers obliged themselves to the research participants not to divulge the information related to the organisation and the informant. The principles of anonymity, volunteerism and benevolence were followed. The social workers were acquainted with the goal of the research, the interview questions, and the importance of argumentated reflection on their experience.

\section{Analysis of research results}

Having left a care home, adolescents begin living independently. It is noted in the Programme of Child Welfare for 2013-2018 and the plan of its implementation (2012) that, in order that those children, who have lost parental care, would integrate into society successfully, it is necessary to develop their independence. Social workers take care of the development of independent life skills in children's care homes and how successful children are in their independent life after leaving care homes depends on the attention social workers allocate to the development of independent life skills.

During the study, it was sought to reveal what directions of the improvement of independent life skills in children are identified by social workers, who work in care institutions, which take part in the restructuring, which consists of the transition from institutional care to the services, that are provided to children, who have lost parental care, in a family and community. When analysing the obtained results of the study 3 directions of the improvement of the educational process of independent life skills: the improvement of the educational process is linked to the increase of the 
independence of the adolescents, the organization of the educational process, the improvement of material basis.

The study results revealed that one of the directions of the improvement of the development of independent life skills is that the increase of independence in children is linked to the engagement of children in a practical activity and their motivation by encouraging and stimulating them for an independent activity (Table 1).

\section{Table 1 The improvement of educational process linked to the increase of independence in children}

\begin{tabular}{|l|l|}
\hline Subcategory & Proving Statements \\
\hline $\begin{array}{l}\text { The } \\
\text { engagement } \\
\text { of children } \\
\text { in a } \\
\text { practical } \\
\text { activity }\end{array}$ & $\begin{array}{l}\text { "...all you need is only a continuous and careful work of our employees, } \\
\text { "...children should be allowed to tidy up themselves. At the present time, a } \\
\text { practice has formed that social workers do the majority of work instead of } \\
\text { children...in order that there would only be orderliness and the director } \\
\text { would not stumble upon it..." (B); “...you need to engage children in a } \\
\text { practical activity: tidying up where they reside, cooking food, ironing their } \\
\text { clothes, putting them neatly..." (G) }\end{array}$ \\
\hline $\begin{array}{l}\text { The } \\
\text { motivation } \\
\text { of children } \\
\text { by } \\
\text { encouragin } \\
\text { g and } \\
\text { stimulating } \\
\text { them for an } \\
\text { independent } \\
\text { activity }\end{array}$ & $\begin{array}{l}\text { "...a social worker, when it comes to a child, should not be a person who } \\
\text { does everything instead of him, but such a person who is close to him, gives } \\
\text { a piece of advice to a child. But a child chooses.... when there is a } \\
\text { complicated situation, you teach, encourage..." (A); “...as much as it is } \\
\text { possible of independence for the educatees themselves since their younger } \\
\text { age...to give a piece of advice to a child, to encourage him for an action, but } \\
\text { not to do instead of him..." (J); "It is important to encourage an adolescent } \\
\text { interests, expectations and possibilities, to actively get engaged in the } \\
\text { achievement of the set goals"(D). }\end{array}$ \\
\hline
\end{tabular}

The social workers pointed out that, in order to engage children in a practical activity, their own consistent, systematic and continuous work is very important. While expanding an independent practical activity (tidying up rooms, cooking food etc.) of children in a daily activity it is important to allow them to act themselves and to accept responsibility for the results of their activity: “... children should be allowed to tidy up themselves, because at the present time...the practice has formed that social workers do the majority of work instead of children... " (B). According to the informants, a vicious practice exists in children's care homes that part of responsibility, which could/should lie with children is transferred on social workers, for example, a social workers receives warnings for untidiness in rooms. Developing skills of budget planning and money management, the promotion of hobbies and interests are equally 
important, in order to avoid social exclusion, as well as the development of selfprotection skills, the strengthening of self-confidence and personal maturity etc. The informants noted that it is important that children, before leaving the care system, would acquire healthcare knowledge and skills. Basic healthcare knowledge encompass first aid, healthy nutrition, physical activity, mental and emotional health, the use of medicaments. It should be noted that it should be avoided to plan an adolescent's independent life without engaging him himself in that process e. g. to find such a place of residence to a former educatee, which does not meet his expectations or needs, to decide instead of an adolescent himself that he is already prepared to live independently and to release to the adult world without any support and aid.

Another direction of the improvement of the development of independent life skills, which came to light during the study, is children's motivation by encouraging and stimulating them to act independently (Table 2).

Table 2 The improvement of the organisation of educational process

\begin{tabular}{|c|c|}
\hline Subcategory & Proving Statements \\
\hline $\begin{array}{l}\text { The increase } \\
\text { of practical } \\
\text { trainings }\end{array}$ & $\begin{array}{l}\text { "In order that adolescents would acquire these skills, there is a need of a } \\
\text { practical teaching, e. g. how to create a lunch menu, to go shopping, to } \\
\text { cook food, to tidy up kitchen, to do the washing up, to properly keep the } \\
\text { remaining food" (H); "...more of practical trainings, the modelling of } \\
\text { various daily life situations (in the bank, when filling in documents, when } \\
\text { visiting a doctor..." (M); "...the educatees lack practice, whereas daily life } \\
\text { skills are developed only while practicing. Therefore, there is a need to } \\
\text { increase practical trainings..." (B); "...the children in households are } \\
\text { becoming more independent, they cook food themselves, develop skills by } \\
\text { interacting with each other... the educational process is becoming } \\
\text { continuous. You educate through your presence..." (C); "...That } \\
\text { improvement, I think, is linked to the changes of the restructuring...the } \\
\text { changes of the life at home will create natural conditions to develop } \\
\text { independence skills. I'm waiting for the closure of that care home, I want to } \\
\text { participate in such process" (L) }\end{array}$ \\
\hline $\begin{array}{l}\text { The decrease } \\
\text { of the } \\
\text { numbers of } \\
\text { educatees in } \\
\text { a household }\end{array}$ & $\begin{array}{l}\text { "...the employees are not able to allocate enough time to the development } \\
\text { of independent life skills in their educatees, because they have too many } \\
\text { educatees... The fewer children are in a household, the more attention is } \\
\text { allocated to each child..." (I); "...the fewer children is an employee } \\
\text { responsible for, the greater possibility is that a particular child will be } \\
\text { worked with more individually, in a more intensive way and more..." (A); } \\
\text { "...I'm waiting for that restructuring,...there will be fewer children, it will } \\
\text { be possible to allocate more time for each child..."(K) }\end{array}$ \\
\hline $\begin{array}{l}\text { The increase } \\
\text { of individual } \\
\text { communicatio } \\
\text { n with a child }\end{array}$ & $\begin{array}{l}\text { "...due to high workload and the number of educates it is impossible to } \\
\text { allocate more time for an individual interaction, whereas it is very } \\
\text { important..." (N); "....it would be good to have more time to communicate } \\
\text { with the educatees individually. It is necessary ...to cut back part of the }\end{array}$ \\
\hline
\end{tabular}




\begin{tabular}{|l|l|}
\hline & $\begin{array}{l}\text { filling of unnecessary documents, other activities in order that a social } \\
\text { worker would have a possibility to allocate more time for individual } \\
\text { trainings with children..." }(\mathrm{G}) ; \text { “....children in households or a guardian } \\
\text { families are becoming more independent, they cook food themselves, } \\
\text { develop skills by interacting with each other, their ties become much more } \\
\text { stable..." (C) }\end{array}$ \\
\hline
\end{tabular}

The informants noted that, when improving the development of independent life skills, it is important to create opportunities for children, since their childhood, to try to perform certain activities independently by encouraging, teaching and stimulating them: “...as much as it is possible of independence for the educatees themselves since their younger age..." (J). The younger an educatee is, the greater are his possibilities to absorb independent life skills and implement them in practical situations and in real life later on. The informants maintained that "... a social worker, when it comes to a child, should not be a person who does everything instead of him, but such a person who is close to him, gives a piece of advice to a child..." (A). It should be noted that the informants has high hopes of the institutional restructuring of children's care: "... maybe in the context of the restructuring when they live not in large care home, but in their own flats or houses children will naturally get engaged in a daily work activity..." (L). The informants underlined that, as a consequence of the restructuring, fundamental changes should take place in the activity of a social worker when preparing children for an independent life. When living in a household a social worker will be the model of behaviour, because there will no longer be cleaners, cooks, sweepers et al. He will get children engaged in activities both when tidying in their household and when shopping and solving problems arising in their household. A social worker will directly teach how to use different services, take care of self etc. According to the informants, "...the organisation of care in households is very favourable. A small number of children in a household and the organisation of care is oriented towards a family life model... I think that when children have an opportunity to see positive behaviour models of the adults they will accept personal responsibility for the performance of certain activities, will develop their work skills, will learn to cope with various life's problems with our assistance" $(\mathrm{G})$.

Another direction of the improvement of the development of independent life skills, which came to light during the study is the improvement of the organisation of educational process (Table 3 ). 


\section{Table 3 The improvement of material basis}

\begin{tabular}{|l|l|}
\hline Subcategory & Proving Statements \\
\hline $\begin{array}{l}\text { The increase of } \\
\text { financial } \\
\text { resources to } \\
\text { develop } \\
\text { independence }\end{array}$ & $\begin{array}{l}\text { "...there is a lack of finances to increase the number of practical trainings } \\
\text { and implement new methods..." (J); "To attract resources when } \\
\text { implementing innovative projects...., to attract local businessmen..."(D) }\end{array}$ \\
\hline $\begin{array}{l}\text { The } \\
\text { redistribution } \\
\text { of the } \\
\text { resources } \\
\text { available }\end{array}$ & $\begin{array}{l}\text { "...I personally think that when restructuring children's care home it is } \\
\text { possible to redistribute the resources of the care home differently, then } \\
\text { more resources will be allocated for practical trainings..." (L); “... we hope } \\
\text { that, while the restructuring is underway, less resources will be allocated } \\
\text { for heating and salaries, but more for the satisfaction of children's needs, } \\
\text { including for the preparation for independent living..." (M); “...perhaps in } \\
\text { the future, when the restructuring has been completed, more resources will } \\
\text { be allocated for education, and less for the maintenance of buildings..."(E) }\end{array}$ \\
\hline
\end{tabular}

The improvement of organisation is linked to the increase of practical trainings, the reduction of the number of educatees in a household and the increase of individual interaction with a child. The informants pointed out that practical trainings hold an important place in the process of the development of independent life skills, therefore, it is necessary to increase them: ,...the educatees lack practice...Therefore, there is a need to increase practical trainings..." (B). The social workers point out that during practical trainings as diverse as it is possible independence skills have to be developed by using, to that end, different forms and methods, such as the modelling of different situations, simulation games, various group trainings, counselling, discussions, roleplays, parental and hygiene skills development consultations, the solution of problematic situations, specific practical tasks during which children would develop independent life skills. According to the informants: "...various practical tasks can be proposed to be performed, for example to take part in a modelled situation of a job interview, to go shopping when having a certain sum of money, to prepare lunch using chosen groceries, to fill in a payment account etc." (J). Facing everyday life situations may stimulate adolescents to more carefully ponder about the available knowledge and skills gaps in certain areas. It should be noted that it is important to be consistent and take into consideration interests and needs of a person himself when preparing children and adolescents for an independent life. Educational process can be organised very creatively by engaging an adolescent. It is likely that educatees will set out to life responsible, mature and independent as a consequence of the restructuring. 
The social workers, who participated in the qualitative study, pointed out that the development of independent life skills would be more effective, if the number of educatees in a household was reduced. They maintain that "...the fewer children are in a household, the more attention is allocated to each child..." (A). The social workers note that when allocating more time for an individual work a child would not only be talked to, but he would be also assisted in acquiring practical skills (filling in documents in a bank, payment of invoices, going shopping and so on). It would assist in ensuring the acquisition of independent life skills by children and their better integration into society.

The participants of the study emphasised that due to high workload of social workers and large number of educatees, a significant number of documents to fill in there is no sufficient time left to an individual interaction with children. The informants underline: "It is necessary ...to cut back part of the filling of unnecessary documents, other activities in order that a social worker would have a possibility to allocate more time for individual trainings with children" $(\mathrm{G})$.

The informants show also the strengthening of material basis as one of the directions of the improvement of the educational process of independent life skills. The participants of the study underlined that the preparation of children for an independent life requires significant financial resources, however, "... there is a lack of finances to increase the number of practical trainings and implement new methods..." (J). Therefore, it is important to look for additional resources when preparing projects by using the resources available to the community, attracting local businessmen etc.

It is possible to strengthen material basis not only by attracting resources, but also by redistributing available resources. The informants noted that the upkeep of large care home buildings and personnel is very expensive, whereas only a small part of the resources remains for educational process. The informants believe that "in the future, when the restructuring has been completed, more resources will be allocated for education, and less for the maintenance of buildings..." (E). Hence, for social workers, the restructuring, which is underway, raises hopes, that are linked to a better preparation for an independent life of children, who are growing up in care homes.

\section{Conclusions}

It is important for a child to grow in a family environment which promotes children's independence, complete participation in the community and social inclusion. The concept of the restructuring of institutional children's care relevancies the restructuring of children's care homes according to the model of a family-like environment. When implementing this model particular attention is 
allocated to the preparation of the children's care homes educatees for an independent life by improving their socialisation and adaptation in the society and perfecting the (self-)development of independent life skills.

Based on the experience of the social workers, the directions of the improvement of the development of independent life skills in children have been highlighted in the context of the restructuring of children's care homes: the increase of adolescents' independence, the improvement of the organisation of educational process, the improvement of material basis. The increase of adolescents' independence is linked to the engagement of children in a practical activity and their motivation by encouraging and stimulating them for an independent activity. The improvement of the organisation of the development of independent life skills is linked to the increase of practical trainings, the reduction of the number of educatees in a household and the increase in the individual interaction with a child. It is proposed to strengthen material basis by attracting new resources and redistributing available resources.

\section{References}

Creswell, J. W. (2009). Research Design: Qualitative, Quantitative, and Mixed Methods Approaches. 3 rd Edition. Los Angeles: Sage Publications.

Common European Guidelines on the Transition from Institutional to Community Based Care. (2012). Downloaded from http://deinstitutionalisationguide.eu/

Hojer, I., \& Sjoblom, Y. (2010). Young people leaving care in Sweden. Child and Family Social Work, 15, 118-127.

Kevmolen, E., \& Broeders, D. (2013). Innocence Lost: Care and Control in Dutch Digital Youth Care. British. Journal of Social Work, 43 (1), 41-63.

Leliūgienè, I., \& Djačenko, V. (2010). Socializacijos centro edukacinė sistema - ugdytiniu tolimesni formaluji mokymąsi lemiantis kompleksinis veiksnys. Socialinis ugdymas, 13(24), 13-30.

Lietuvos Respublikos Seimo 20030520 d. nutarimas Nr. IX-1569 „Dèl vaiko gerovès valstybès politikos koncepcijos. (2003). Valstybès žinios, 52-2316.

Lietuvos Respublikos socialinès apsaugos ir darbo ministro $2014 \mathrm{~m}$. vasario $14 \mathrm{~d}$. Isakymas Nr. A1-83. Perèjimo nuo institucinès globos prie šeimoje ir bendruomeneje teikiamu paslaugu neigaliesiems ir likusiems be parents globos vaikams 2014-2020 metu veiksmu planas. (2014). Downloaded from https://www.e-tar.lt/portal/lt/legalAct/c90d 41f097de11e3bdd0a9c9ad8ce1bf

Lietuvos Respublikos Vyriausybès 20071031 d. nutarimas Nr. 1193 „Dèl vaiko globos (rūpybos) sistemos reorganizavimo strategijos ir jos igyvendinimo priemoniu 2007 2012 metų plano patvirtinimo“. (2007). Valstybès žinios, 118-4817.

Pūras, D. (2013). Institucinè globa - vaiku iki treju metu teisiu pažeidimas. Downloaded from https://www.hrmi.lt/uploaded/PDF\%20dokai/LT_D.Puras_Children\%20under\%203.pdf

Rèklaitienė D. ir kt. (2008). Tèvu globos netekusiu asmenu gyvenimo kokybès ir pasirengimo savarankiškam gyvenimui èvertinimas: tyrimo ataskaita. Socialinès apsaugos ir darbo ministerija. Downloaded from http://www.socmin.lt/public/uploads/750_tevu_globos_ netekusiu_asmenu_gyvenimo_kokybes_ivertinimas.pdf 
Vida Gudžinskienè, Rita Raudeliūnaitè. The Improvement of Children's Independent Living Skills in the Context of the Restructuring of Children's Care Homes

Samašonok, K. (2013). Globos namuose gyvenančių children ir paauglių savarankiško gyvenimo igūdžių ugdymas: pasiekimai, sunkumai, sprendimai. Pedagogika, 110, 103-114.

Snieškienè, D., \& Bumblauskaitè, K. (2005). Globos istaigoje augančių jaunuoliu pasiruošimas savarankiškam gyvenimui. Specialusis ugdymas, 2 (13), 111-122.

Strolin-Goltzman, J. et. al. (2010). Listening to the Voices of Children in Foster Care: Youths Speak Out about Child Welfare Workforce Turnover and Selection. Social Work, 55(1), 47-53.

Valstybinio audito ataskaita. Ar children globos sistema atitinka globojamo vaiko interesus. (2014).

Vaiko gerovès 2013-2018 metu programa. (2012). Valstybès žinios, 140-7208 .

Valstybès Vaiko teisiu apsaugos ir ívaikinimo tarnybos prie Socialinés apsaugos ir darbo ministerijos 2014 metu veiklos ataskaita (2015). Downloaded from http://vaikoteises.lt/media/file/ataskaitos/2014\%20M_\%20VEIKLOS\%20ATASKAITA $\% 202015-03-18 . p d f$ 